Original Research Article

\title{
Anticonvulsant effects of nimodipine alone and combination with phenytoin on MES induced seizures
}

${ }^{1}$ Department of Pharmacology, ${ }^{2}$ Department of Biochemistry, PCMS \& RC, Bhopal, Madhya Pradesh, India

Received: 24 March 2018

Revised: 05 April 2018

Accepted: 25 April 2018

*Correspondence to:

Dr. Ashish Jain,

Email: jaindrashish@

yahoo.co.in

Copyright: (C) the author(s), publisher and licensee Medip Academy. This is an openaccess article distributed under the terms of the Creative Commons Attribution NonCommercial License, which permits unrestricted noncommercial use, distribution, and reproduction in any medium, provided the original work is properly cited.

\author{
Raina Jain ${ }^{1}$, Ashish Jain ${ }^{2 *}$
}

\begin{abstract}
Background: To evaluate the anticonvulsant activity of Nimodipine alone and in combination with Phenytoin, in MES induced seizures.

Methods: The study was conducted in mice and MES seizure was induced by Techno electroconvulsometer. In first part of study, animals were treated with Nimodipine $(20 \mathrm{mg} / \mathrm{kg}$ i.p. and $40 \mathrm{mg} / \mathrm{kg}$ i.p. $)$ and Phenytoin $(0.5 \mathrm{mg} / 100 \mathrm{~g}$ i.p. and $1.0 \mathrm{mg} / 100 \mathrm{~g}$ i.p.), MES was induced and durations of various phases were noted. Duration of Tonic hind limb extension (THLE) was taken as index for antiepileptic activity. In second part, the animals were treated with combination of sub effective doses of Nimodipine (20mg/kg i.p.) and Phenytoin $(0.5 \mathrm{mg} / 100 \mathrm{~g}$ i.p.), MES was induced and durations of various phases were noted.

Results: Nimodipine produced significant antiepileptic activity, in dose dependent manner. Phenytoin produced significant antiepileptic effect in dose of $1.0 \mathrm{mg} / 100 \mathrm{~g}$ but failed to produce any such effect in dose of $0.5 \mathrm{mg} / 100 \mathrm{~g}$, when administered alone. But when sub effective doses.

Of Nimodipine and Phenytoin were combined, a synergistic effect was seen.

Conclusions: Nimodipine possess significant antiepileptic activity, alone, as well as it potentiates the antiepileptic effect of Phenytoin, suggesting the novel application of already proven safe and efficacious calcium channel blockers.
\end{abstract}

Keywords: MES, Nimodipine, Phenytoin, Synergism, THLE

\section{INTRODUCTION}

Epilepsy is the second most common neurological disorder in India. ${ }^{1,2}$ John hughlingson Jackson, The father of modern concept of epilepsy, proposed that seizures were caused by occasional, sudden, excessive, rapid and local discharges of gray matter. There is an important role of synapses and defective synaptic function i.e., reduction in inhibitory or enhancement of excitatory activity, might lead to seizures. Many other factors were also identified, including volume of the extracellular space as well as intrinsic properties of neurons such as voltage regulated ion channels, including calcium ions. ${ }^{3}$ The alteration in state is the result of an abnormal and excessive hypersynchronous firing of epileptic neurons in the brain. ${ }^{4}$ The influx of calcium ions through channels in cellular membrane plays a pivotal role in many physiological and physiopathological processes. ${ }^{5}$ Since calcium channel blockers have been effective in a variety of cardiovascular ailments, it is predictable that these drugs may be of value in treating those pathological states where over activity of calcium channel is apparent, because the excitability of these tissue are functionally dependent on the influx of extracellular calcium ions. ${ }^{6}$ Calcium ions play a central role in the control of neuronal excitability. ${ }^{7}$ Intensive research has highlighted that calcium is an important factor involved in epileptogenesis and neurotoxicity during status 
epilepticus. ${ }^{8,9}$ Based on the facts of the role of calcium ions in excitability of various tissues, calcium channel antagonists have been studied and results shows the blockade of various aspects of epileptogenesis and are effective anticonvulsants in a number of in-vivo models. ${ }^{10-12}$ Thus the present study was undertaken to investigate the anticonvulsive activity of nimodipine, a cerebroselective DHP, blocking L type calcium channels. BAY K-8644, an agonist at the DHP binding site of L type calcium channel, was found to diminish the protection offered by conventional antiepileptic drugs (carbamazepine, diphenylhyadantoin, Phenobarbital), against MES induced seizures, indicating that some of the conventional antiepileptic drugs partially exerts their anticonvulsive effects via blockade of calcium influx. ${ }^{13}$ keeping in mind the above fact, as well as, the toxicity and teratogenecity of PHENYTOIN, which is a conventional antiepileptic drug, the present study was extended to see, if there is any synergistic effect of the combination of Nimodipine with Phenytoin, against MES induced seizures.

\section{METHODS}

\section{Animals}

Adult, healthy swiss albino mice, aged 6-8 weeks of either sex weighing 20-30 g were used. They were housed under standard laboratory conditions [controlled temperature (around $22+/-2^{\circ} \mathrm{C}$ ) and humidity $(50 \%)$ colony room] for one week before experiments were started and were kept in groups of 3-4 in per polypropylene cages. Animals were allowed standardized diet and water ad libitum, except for the period of experimentation.

\section{Drugs and chemicals}

- $\quad$ Nifedipine (JB chemicals, Mumbai)

- Phenytoin sodium (smarth pharma, Mumbai) - an aqueous solution was freshly prepared in distilled water just before use.

The animals were grouped, comprising of 10 animals in each group. Saline treated animals were served as control. Maximal electroshock seizure was induced by Technoelectroconvulsometer (50 mAmp for $0.1 \mathrm{sec})$, through ear electrode, via small alligator clips. Duration of various phases of MES seizures (tonic flexion, tonic extension, clonic convulsion, and post tetanic depression) were noted with the help of stop watch.

In the first phase, the animals were treated with Nimodipine $(20 \mathrm{mg} / \mathrm{kg}$ i.p.). MES was induced by techno electroconvulsometer, 2 hours after the administration of the drug, and various phases were noted.

In the second phase, the dose of Nimodipine was increased to $40 \mathrm{mg} / \mathrm{kg}$, and durations of various phases MES induced seizure were noted.
In next phase of study, animals were injected Phenytoin $(0.5 \mathrm{mg} / 100 \mathrm{~g}$ i.p.) and MES was induced $1 \mathrm{hr}$ after Phenytoin administration and various durations were noted. This dose of Phenytoin was increased to $1.0 \mathrm{mg} / 100 \mathrm{~g}$, and duration of various phases of MES induced seizure was noted.

The study was further extended to see the synergistic effect of combination of Nimodipine and Phenytoin. For this, the animals were treated with Phenytoin $(0.5 \mathrm{mg} / 100 \mathrm{~g}$ i.p. $)$ and Nimodipine (20mg/kg i.p.). CCB was administered $1 \mathrm{hr}$ before Phenytoin administration and MES was induced 1 $\mathrm{hr}$ after Phenytoin administration and durations of various phases of MES induced seizure were noted.

Results were statistically analyzed by unpaired student's t test. $\mathrm{p}$ values $<0.05$ were considered significant.

\section{RESULTS}

The present study was undertaken to explore the anticonvulsant effects of Nimodipine and keeping in mind the adverse effects, toxicity, and teratogenic effects of Phenytoin, the study was extended to see if there is any synergistic effect of the combination of Nimodipine with Phenytoin, in MES induced seizures. The experimental study was conducted in mice. Each study was conducted with control group treated with distilled water. The abolition or reduction of Tonic hind limb extension (THLE) was considered as index for antiepileptic activity.

On per se administration, Phenytoin ( $1 \mathrm{mg} / 100 \mathrm{~g}$ i.p.) significantly reduced the duration of THLE $(p<0.001)$, in all groups studied, but, in the dose of $0.5 \mathrm{mg} / 100 \mathrm{~g}$ i.p., Phenytoin failed to produce any significant alteration in any phase of MES induced seizures.

When administered alone, Nimodipine, in the dose of, $20 \mathrm{mg} / \mathrm{kg}$ i.p., produce significant reduction in THLE $(p<0.01)$, but in dose of, $40 \mathrm{mg} / \mathrm{kg}$ i.p., the effect of Nimodipine increased and there is reduction in duration of THLE $(\mathrm{p}<0.001)$, in a dose dependent manner.

\section{Table 1: Effects of different doses of nimodipine and phenytoin on THLE.}

\begin{tabular}{|c|}
\hline Dose THLE \\
\hline Control $13.9 \pm 1.19$ \\
\hline Nimodipine $(20 \mathrm{mg} / \mathrm{kg}) 8.70 \pm 0.67 *$ \\
\hline Nimodipine $(40 \mathrm{mg} / \mathrm{kg}) 2.43 \pm 1.15 * *$ \\
\hline Phenytoin $(0.5 \mathrm{mg} / 100 \mathrm{~g}) 14.0 \pm 1.4 * * *$ \\
\hline Phenytoin $(1.0 \mathrm{mg} / 100 \mathrm{~g}) 2.2 \pm 1.70 * * * *$ \\
\hline $\mathrm{N}+\mathrm{P}(20 \mathrm{mg} / \mathrm{kg}+0.5 \mathrm{mg} / 100 \mathrm{~g}) 2.8 \pm 1.37 * * * *$ \\
\hline
\end{tabular}

With combined administration of subeffective doses of Nimodipine (20mg/kg i.p.) and Phenytoin $(0.05 \mathrm{mg} / 100 \mathrm{~g}$ i.p.), potentiation of antiepileptic effect of Phenytoin was 
observed, that is, there was significant reduction in the duration of THLE $(\mathrm{p}<0.001)$.

\section{DISCUSSION}

The anticonvulsant effect of calcium antagonists through inhibition of calcium entry via voltage dependent L type channels has been investigated in some in-vitro and invivo studies. ${ }^{14}$ The L type calcium channel (DHP Channel) is part of the high voltage activated family of voltage dependent calcium channel. This channel has four subunits- Cav 1.1, Cav 1.2, Cav 1.3 Cav 1.4. ${ }^{15}$ Nimodipine, which is a cerebroselective calcium antagonist that blocks the voltage dependent $\mathrm{L}$ type channel. Its antiepileptic properties have been proved in various animal models. A statistically significant reduction in epileptic activity was seen by Nimodipine, in Cefazoline (applied cortically) induced epilepsy in rabbit. ${ }^{16}$ In a further study, Nimodipine has been found to attenuate excitability by blocking calcium influx in kainic acid induced membrane depolarization. ${ }^{17}$ Nimodipine also proved efficient against PTZ induced seizures. ${ }^{18}$ Anticonvulsant effect of 1,4 dihydropyridine (bis - DHP) has also been proved in male CF1 mice, on PTZ epileptic model. ${ }^{19}$ The results of present study were in support of the previous studies, showing significant antiepileptic activity of NIMODIPINE, which significantly reduced the duration of THLE $(p<0.001)$. Further, the potentiation of antiepileptic effect of PHENYTOIN was observed, when sub effective doses of Nimodipine and Phenytoin were combined. The possible action of the anticonvulsant action of CCBs is the potent antagonism of transmembrane calcium neurons and disturbances in neuronal calcium conductance, which is implicated in generation and propagation of seizure activity. ${ }^{20}$ Nimodipine is lipid soluble and can cross BBB with ease, hence cerebrovascular effects (vasodilatation) of Nimodipine, could provide a direct neuroprotective effect against the damaging influx of calcium. ${ }^{21}$ Phenytoin sodium exerts antiepileptic effect by stabilization of neuronal membrane and thus prolongation of recovery of inactivated sodium channels, but in high dose, it can also block the calcium influx during depolarization. ${ }^{22,23}$ Phenytoin also inhibits post tetanic potentiation probably by inhibiting this calcium influx. ${ }^{24}$ Phenytoin and the classical calcium channel antagonists inhibits voltage gated calcium influx by different but functionally linked mechanism. Thus they have synergistic effects. ${ }^{25,26}$ To conclude, the control of permeability of calcium ions through DHP calcium channels is considered a strategy for the development of anticonvulsant activity.

Funding: No funding sources

Conflict of interest: None declared

Ethical approval: The study was approved by the Institutional Ethics Committee

\section{REFERENCES}

1. Bharrucha NE. Epidemiology of epilepsia in india. Epilepsia. 2003;44:9-11[pubmed].
2. Gourie-Devi M, Gururaj G, Satishchandra P, Subbakrishna DK. Prevalence of neurological disorders in Bangalore, India: A community-based study with a comparison between urban and rural areas. Neuroepidemiology. 2004;23:261-8 [pubmed].

3. James O MC Namara. Drugs effective in the therapy of epilepsies. In Goodmann Gilman's Pharmacological Basis of Therapeutic, Hardman JG, Limbard LE, Gilman AG, Mc Graw Hill, New York; $10^{\text {th }}$ Edition; 2001:724-760.

4. Cheng LS, Prasad AN, Reider MJ. Relationship between antiepileptic drugs and biological markers affecting long term cardiovascular function in children and adolescents. Can J Clin Pharmacol. 2010;17:45-6 [pubmed].

5. Shehata GA, Bateh Ael-A, Hamed SA, Rageh TA, Elsorogy YB. Neurophysiological effects of antiepileptic drugs (carbamazepine verse valproate) in adult males with epilepsy. Neuropsychiatry Dis Treat. 2009;5:527-33 [pubmed].

6. Desai CK, Dikshit RK, Mansuri SM, Shah UH. Comparative evaluation of anticonvulsant activity of CCBs in experimental animals. Ind J of Experi, Mental Biology. 1995;33:931-34.

7. Larkin JG, Thompson GG, Scobie G, Forrest G, Drennan JE, Brodie MJ. Dihydropyridine calcium channel antagonists against pentylenetetrazole seizures, Epilepsia. 1992;33:760-9.

8. Hilmar B. Nuclear calcium activated gene expression: Possible roles in neuronal plasticity and epileptogenesis. Epilepsy Research. 1999;36:225-31.

9. Berg M, Bruhn T, Frandsen A, Schousboe A, Diemer NH. Kainic acid induced seizures and brain damage in the rat; Role of calcium homeostasis. J Neurusci Res. 1995;40:641-6.

10. Wurpel JN. Calcium channel blockers verapamil and nimodipine inhibit kindling in adult and immature rats. Epilepsia. 1994;35:443-9.

11. Palmer GC, Stagnitto ML, Ray RK, Knowles MA, Harvey R, Garske GE. Anticonvulsant properties of calcium channel blockers in mice: N-methyl-D-Laspartate and Bay 448644 induced convulsions are potently blocked by the dihydropyridines. Epilepsia. 1993;34:372-80.

12. Meyer FB, Anderson RE, Sundt TM, Sharbrough FW. Selective central nervous system calcium channel blockers- a new class of anticonvulsant agents. In Mayo Clinic Proceedings. Elsevier. 1986;61(4):23947.

13. Gasior M, Kleinrok Z, Czuczwan SJ. Influence of BAY K - 8644, a calcium channel antagonist on the anticonvulsant activity of conventional antiepileptics against electroconvulsions in mice. Neuro Pharmacology. 1995;34(4):433-8.

14. De Sarro GB, Meldrum BS, Nistico G. Anticonvulsant effects of some calcium entry blockers in DBA/2 mice. Br J Pharmacol. 1988;93:247-56.

15. Rossier, Michel F. T type calcium channel: A priviledge gate for calcium entry and control of 
adrenal steroidogenesis. Frontiears in endocrinology.7. 2016.

16. Morocutti C, Pierelli F, Sanarelli L, Stefano E, Peppe A, Mattioli GL. Antiepileptic effects of a calcium channel antagonist (Nimodipine) on CFZ induced epileptic foci in rabbits. EPILEPSIA. 1986;27(5):498503.

17. Mikati MA, Holmes GL, Werner S, Bakkar N, Carmant L, Stafstrom CE. Effects of Nimodipine on the behavioral sequelae of experimental status epilepticus in prepubescent rats. Epilepsy behaves. 2004;5(2):168-74.

18. Neil OSK, Bolger GT. The effects of dihydropyridine calcium channel modulators on PTZ. Brain Res Biull. 1990;25(1):211-4.

19. Ramírez-San Juan E, Soriano-Ursúa MA, EspinosaRaya J, Correa-Basurto J, Trujillo-Ferrara JG, Miranda-Ruvalcaba R, et al. Anticonvulsant effects of bis-1, 4-dihydropyridines and the probable role of $\mathrm{L}$ type calcium channels suggested by docking simulations. Medicinal Chemistry Research. 2014 Dec 1;23(12):5149-59.

20. Tartara A, Galimberti CA, Manni R, Parietti L, Zucca L, Laresia L, et al. Differential effects of valproic acid and enzyme including anticonvulsants on Nimpodipine pharmacokinetics in epileptic patients. Br J Clin Pharmacol. 1991;32:335-40 [pubmed].

21. Czuczwar SJ, Tutski L, Turski W, Kleinrok Z. Effects of some antiepileptic drugs in PTZ induced convulsions in mice lesioned wth kainic acid. Epilepsia.1981;22:407-14[pubmed].

22. Mclean MJ, Madonal RL. Multiple actions of phenytoin on mouse spinal cord neurons in cell culture. J Pharmacol Exp Ther. 1983;227:779-89.

23. Narahashi T, Baker PF. Drugs acting on calcium channels. Handbook of experimental pharmacology. Vol. 83; Berlin Springer verlag. 1988:225-274.

24. Katzung BG. Basic and clinical pharmacology; $6^{\text {th }}$ Edition. East Narwalk. Appleton and Lange, 1995;225-274.

25. Messing RO, Capenter CL, Greenberg DA: Mechanism of calcium channel inhibition by Phenytoin: Comparison with classical calcium antagonists. J Pharmacol Exp Ther. 1985;235(2):40711 .

26. Kryzhanovskii GN, Karpora MN, Abrosimov 2 U, Pankov OIU, Lakinia MV. The anticonvulsant activity of sodium valproate and various calcium antagonists during their combined use in mice. Biull Eksp Biol Med. 1993;115(3):231-3.

Cite this article as: Jain R, Jain A. Anticonvulsant effects of nimodipine alone and combination with phenytoin on MES induced seizures. Int J Basic Clin Pharmacol 2018;7:1160-3. 